\title{
Profile of children adolescents and their caregivers assisted by a Home Care Program
}

\author{
Perfil de crianças adolescentes e seus cuidadores assistidos por um Programa de Atenção \\ Domiciliar
}

Fernanda Elisa Pereira Mariani ${ }^{1}$, Elysângela Dittz Duarte ${ }^{2}$, Bruna Figueiredo Manzo ${ }^{2}$

\begin{abstract}
Objective: to identify the sociodemographic and clinical profile of children, adolescents and caregivers assisted by a Home Care Program. Methods: a descriptive, exploratory and retrospective study. 42 medical records data from patients aged between zero and 18 years were collected. Results: the population assisted in the program was predominantly male (61.9\%), less than 6 years (59.5\%) diagnosed with neurological diseases (40.0\%). Most patients had up to ten visits of the multidisciplinary team (40.5\%), those patients remained in the Home Care Program for 6 months. Regarding therapeutic procedures, $42.9 \%$ of the patients underwent gastrostomy and $31.0 \%$ underwent tracheostomy. As for the caregivers, 95\% were women, and of these, $52.4 \%$ did not work. Conclusion: the main conditions of health and the care required during the hospitalization by the program were identified, which require training of the health professionals to perform this task at home.
\end{abstract}

Descriptors: Home Care Services; Pediatrics; Public Health.

Objetivo: identificar o perfil sociodemográfico e clínico de crianças, adolescentes e cuidadores assistidos por um Programa de Atenção Domiciliar. Métodos: estudo descritivo, exploratório e retrospectivo. Foram coletados dados de 42 prontuários de pacientes com idade entre zero e 18 anos. Resultados: a população atendida no programa foi predominantemente do sexo masculino (61,9\%), menor de 6 anos (59,5\%), com diagnóstico de agravos neurológicos $(40,0 \%)$. A maioria dos pacientes recebeu até dez visitas da equipe multiprofissional $(40,5 \%)$ e vinculou-se ao Programa de Atenção Domiciliar por 6 meses. Em relação aos dispositivos terapêuticos, $42,9 \%$ dos pacientes usavam gastrostomia e 31,0\% apresentavam traqueostomia. Quanto aos cuidadores, $95 \%$ eram mulheres e, destas, 52,4\% não exerciam atividade laboral. Conclusão: foram identificadas as principais condições de saúde e os cuidados demandados durante a internação pelo programa, os quais exigem preparo dos profissionais para sua realização no domicílio.

Descritores: Serviços de Assistência Domiciliar; Pediatria; Saúde Pública.

\footnotetext{
${ }^{1}$ Centro de Formação de Enfermagem de Minas Gerais, Hospital Belo Horizonte. Belo Horizonte, MG, Brazil.

${ }^{2}$ Universidade Federal de Minas Gerais. Belo Horizonte, MG, Brazil. 


\section{Introduction}

Home care is an alternative to the increasing number of patients with chronic diseases who require continuous comprehensive care. It is a method in the field of rehabilitation and health promotion, aimed at the quality of health actions in the area (1). It is a strategy that pursuits the reversal of the hospital-centered model and the expansion of health care coverage to patients with chronic diseases ${ }^{(1-3)}$, especially when enabling care to the patient resulting from nuances of care. It has advantages as follows: individualized and more humanized care, greater participation of the family, possibility to remain at home, and decreased risk of hospital infections and government expenditures ${ }^{(4)}$.

The World Health Organization considers that home care is a health service which aims at assisting individuals in any age group, making it possible for the care that previously required hospitalization to be performed at home and in the community ${ }^{(5)}$.

The role of nursing staff in home care is regulated by Resolution of the Federal Council of Nursing ${ }^{(6)}$, one of the attitudes expected from nurses is to be a mediator between the caregiver and the care actions developed. This professional is responsible for identifying clinical changes and evaluating the social network of care involved, identifying the skills and difficulties of caregivers ${ }^{(7-8)}$.

In Brazil, children who require continuous care of health, including those dependent on technology, have their social vulnerability increased due to the scarcity of public policies ${ }^{(9-10)}$. There is still lack of national records of prevalence of children dependent on technology at home. A study made in Santa MariaRS, Brazil, showed that the complications with babies coming from neonatal therapy requiring specialized health care were $58.5 \%{ }^{(11)}$.

That confirms the need for the production of knowledge about the characterization of households, the profile of the children and their caregivers, and the care required, in order to favor integration with public policies and also to implement care practices, among them those based on fundamental knowledge of nursing.

The city of Belo Horizonte-MG, Brazil, setting of this study, has a population over 100,000 inhabitants, it contemplates the criterion of existence of public services of home care and it was selected for the implementation of political strategies in this scope, the levels of primary, outpatient or hospital care. Under this perspective, the county instituted the Home Care Program in the county, state, federal and philanthropic public units ${ }^{(1)}$.

Regarding the children, object of this study, the Home Care Program has specific criteria to assist children who require special care, with the main diagnoses related to genetic and neurological diseases acquired in the first months of life. The ones diagnosed with terminal stage requiring palliative care were inserted in this context, as well as those with chronic diseases, dependent on procedures such as oxygen therapy, mechanical ventilation, gastrostomy, parenteral nutrition or medication, therefore they need nursing assistance ${ }^{(12)}$.

The program offers technical and scientific support and promotes the autonomy of patients and/ or caregivers who are responsible for the care, with health professionals, decreasing the susceptibility to complications resulting from the use or improper technique of procedures, such as the incorrect administration of drugs ${ }^{(3-5,12)}$.

The production of knowledge about home care in the pediatric population and their families is limited, indicating the need for productions that leverage this kind of assistance as well as contribute to a comprehensive, safe and quality care. Thus, it was defined as objective of this study to identify the 
sociodemographic and clinical profile of children, adolescents and caregivers assisted by a Home Care Program.

\section{Methods}

It is a study descriptive, exploratory and retrospective type. The study was made with data from the Home Care Program of a university hospital in the city of Belo Horizonte. In this program, home care in pediatrics was accomplished through the planning of the steps of assistance, whose regulations included the indication of the patient, and the development and implementation of a treatment plan assured up to the time of hospital discharge. The patients who were hospitalized in the institution, lived near the area covered by the Basic Health Unit, and who had the consent of the family or responsible caregiver and fixed housing with conditions to host them, were included in the program.

For the data collection, the registers of information on the services rendered to children and adolescents assisted in the period from October 2010 to October 2012, including all doctor records, totaling 42 people attended, were used.

An instrument created by the authors, which allowed to obtain sociodemographic and clinical data, was used. The following variables were collected from the medical records: sex, age, skin color, place of residence, diagnosis concerning the hospitalization in the program, class of medications used during hospitalization in the program and number of visits received during home care. The variables for characterization of caregivers were sex, education, occupation and marital status.

The data were transferred to a databank inserted in the Statistical Package for Social Sciences, version $17.0^{\circledR}$, and were submited to descriptive analyses of frequency of events.

The study complied with the formal requirements contained in the national and international regulatory rules of research involving human beings.

\section{Results}

42 children and adolescents were studied, of which 25 (59.5\%) lived in Belo Horizonte and 17 $(40.5 \%)$ in the metropolitan area, predominantly male $(61.9 \%)$ in the age group ranging from zero to 6 years (59.5\%), and 15 to 18 years old (35.7\%). Information for observation of skin color were not registered in 22 (52.4\%) medical records.

Regarding the clinical profile of children and adolescents, the following issues were observed: the diagnoses for the hospitalization in the Home Care Program, the classes of drugs used during the monitoring by program, and the use of therapeutic aids (tracheostomy and gastrostomy) and neurological devices (ventricular peritoneal shunt and external ventricular shunt), and the type of food used. It is worth highlighting that each of the participants had more than one simultaneous occurrence for each of those variables.

During the monitoring period in the Home Care Program, most children and adolescents had more than one diagnosis, which referred especially to diseases of neurological etiology (40.0\%), followed by respiratory diseases $(29.0 \%)$, genenitc $(29.0 \%)$ and neoplasms (26.0\%). Regarding the use of drugs by patients, multivitamins were the most common (45.0\%), followed by anticonvulsants (40.0\%). anxiolytics, hypnotics and antidepressants totaling $34.0 \%$, antacids, $24.0 \%$ and antineoplastic $21.0 \%$ (Table 1). 
Table 1 - Medical diagnosis of the hospitalization and classes of drugs used in the Home Care Program

\begin{tabular}{lc}
\hline Variables & n (\%) \\
\hline Diagnosis of hospitalization & $17(40.0)$ \\
Neurological & $12(29.0)$ \\
Genetic & $12(29.0)$ \\
Respiratory & $11(26.0)$ \\
Neoplastic & $8(19.0)$ \\
Cardiac & $5(12.0)$ \\
Metabolic & $4(10.0)$ \\
Gastrointestinal & $1(2.0)$ \\
Psychological & $1(2.0)$ \\
Renal & \\
Classes of drugs & $19(45.0)$ \\
Multivitamins & $17(40.0)$ \\
Anticonvulsants & $14(34.0)$ \\
Anxiolytics and hypnotics/antidepressants & $10(24.0)$ \\
Antacids & $10(24.0)$ \\
Corticosteroids/antibiotics & $9(21.0)$ \\
Antineoplastic & $8(20.0)$ \\
Antihypertensive/bronchodilators & $6(14.0)$ \\
Analgesics & \\
\hline
\end{tabular}

As for therapy, $42.9 \%$ underwent gastrostomy, $31.0 \%$ underwent tracheostomy and 16.7\%, ventricular peritoneal shunt during the period of assistance by the Home Care Program. Regarding the food, $45.2 \%$ used special industrialized formula and home food concomitantly, and $23.8 \%$ only used industrialized food.

Concerning the caregivers, the mother was the primary caregiver $(95.0 \%) ; 57.1 \%$ were married or living in a stable union, and $52.4 \%$ did not work outside the home environment. School record of caregivers were not shown in $54.8 \%$ of the records. However, those who were chosen, $28.6 \%$ had highschool education, followed by $14.3 \%$ with gradeschool.

As for the monitoring period of assistance by the Home Care Program, $73.8 \%$ of children and adolescents were monitored for a period of less than six months.

\section{Discussion}

The change in the health profile of the population and the increase in the life expectancy enabled the creation of a new perspective in health care: home care. It is a welfare technological model that requires investments in public health. This type of care began in the United States and allows the development of actions at home that achieve the three levels of care (primary, secondary and tertiary), favoring health promotion, self-care and the prevention of diseases and risks. It can be divided into home assistance/care and hospitalization, according to the complexity of procedures and health technologies involved ${ }^{(13)}$.

Home Care programs established throughout the country enable a greater number of children to be assisted, thus allowing a continuous, humanized and quality assistance.

Although this is a current and effective strategy for health promotion in Brazil, focused on caregiver/ patient dyad, there are programs which are below to what is recommended to obtain a health care scenario adequate to the improvement of the quality of life of the population. There is still a lack of full service skills such as public health policies; planning and implementation; partnerships, collaboration, support and leadership ${ }^{(14)}$.

The knowledge of the sociodemographic and clinical profile of children, adolescents and their caregivers can contribute to the achievement of some of these skills. In this research, it became clear that, in the Home Care Program, patients were mostly less than 6 years of age, had more than one health problem and used continuous medications such as multivitamins, anticonvulsants anxiolytics, hypnotics and antidepressants, besides having undergone tracheostomy and ventricular peritoneal shunt.

The knowledge of this profile explains the need of planning for care that covers varied complexity actions, from identification of demands of material and technological resources to make the continuous care at home and the necessary logistics feasible as 
well as the knowledge and necessary skills to the team that will assist the families and their patients.

It was also observed that the most common diagnoses in children during the period of inclusion in the program were neurological, respiratory, genetic and neoplastic diseases. The data found here agree with the survey made in 2004, in which the neurological diseases are more representative $(27.0 \%)$, followed by neoplastic diseases $(17.0 \%)^{(15-16)}$. This fact is described similarly in a study made in Santa Maria, in 2004 and $2005^{(11)}$.

In the study which evaluated the condition of the child coming from a intensive care unit, the use of trace elements and anticonvulsants had a higher prevalence and also pointed the use of gastrostomy, ventricular peritoneal shunt catheters for dialysis and the use of chemotherapy as well as the usual care such as bathing, changing position, changing clothes, infection prevention and skin care ${ }^{(17)}$. This factor confirms the data found in this study, in which multivitamins and anticonvulsants were the most commonly used classes of drug, just as the most used therapeutic procedures were gastrostomy, tracheostomy and ventricular peritoneal shunt.

The care provided in home care programs have brought a direct impact in the hospital discharge rate, which implies greater availability of hospital beds for patients assisted in a situation of emergency and in critical health condition. This discussion is shown in a study that describes home hospitalization in the National Health System, to present the benefits of home care in Fortaleza, CE, Brazil, with the creation of the Program Homecare of Ventilatory Assistance ${ }^{(18)}$.

In this research, the authors stressed that the creation and development of the program made it possible to reduce hospital infections and deaths, according to rates stablished by the National Health Surveillance Agency. These data support the need for investments in studies intended for home care, given the possibility of increased survival of patients with chronic diseases linked to dependence on health technology resources ${ }^{(18)}$.
Although with obvious benefits, the implementation of the Home Care Program brought discussions on the role of the family and the primary caregiver. The program supports the maintenance of its actions concerning the caregiver, whether formal or informal, generating overload charges, doubts and uncertainties from those who have such role. The mother is presented as the primary caregiver of children under chronic conditions, taking the responsibility to solve the needs of the child, living the overload and affect dyad ${ }^{(15)}$.

In the present study, the mother was the protagonist of care, so attention also needs to be directed to her during home care. The moments of the home visit are appropriate to approach and recognize the challenges and the opportunities that mothers have to ensure the care of the children. Different information and observation can be used by the team so that, with the caregiver, can formulate strategies of care for the mother and child. There is no need to create possibilities to ease the burden resulting from the numerous activities undertaken by caregivers.

The low schooling of the caregiver in this study was similar to other studies of this nature ${ }^{(16-17)}$, probably because it is a sample of the public health service, which does not have resources to pay for another caregiver, overloading the maternal role in the household. It is therefore crucial that professionals inserted in the Home Care Program develop systematic guidance to caregivers. Proposals of guidelines should observe and respect the culture, creativity and the physical proximity of the caregiver to the care receiver ${ }^{(14)}$.

Health professionals should use different training strategies, considering the reality of each individual and family, providing individualized, humanized and safe care ${ }^{(13,18)}$. They should also develop skills to transmit knowledge in the best way, so that care is rendered to ensure the recovery of the patient and the maintenance of health with better quality of life for caregivers and care receivers ${ }^{(14)}$. 


\section{Conclusion}

The research allowed to know the profile of the population assisted by a pediatric Home Care Program, which had mostly children between zero and six years, patients with neurological, respiratory, genetic and neoplastic disorders. Gastrostomy, tracheostomy and peritoneal shunt ventricle were the most used procedures. Almost all of the caregivers were women, and most of them did not work.

The quality of information available in the medical records needs improvement, especially in the description of information on the caregiver, in the attention of the handwriting, which sometimes was not legible or unintelligible, complicating a more accurate diagnosis of the care rendered at home.

The results enable a more effective targeting of care for children with special health care needs and nurture the development of joint actions of the team with the caregivers, thus ensuring care and support for mother and child related to the care rendered by the mother in this home and care process.

\section{Collaborations}

Mariani FEP contributed to the conception, analysis, data collection, interpretation of the data and writing of the article. Duarte ED and Manzo BF contributed to the conception, analysis, interpretation of the data, writing of the article and the final approval of the version to be published.

\section{References}

1. Silva KL, Sena RR, Seixas CT, Feuerwerker LC, Merhy EE. Atenção domiciliar como mudança do modelo tecnoassistencial. Rev Saúde Pública. 2010;44(1):166-76.

2. Ministério da Saúde (BR). Secretaria de Atenção à Saúde, Departamento de Atenção Básica. Programa Melhor em Casa. A segurança do hospital no conforto de seu lar. Brasília: Ministério da Saúde; 2012.
3. Brito MJ, Andrade AM, Caçador BS, Freitas LF, Penna CM. Atenção domiciliar na estruturação da rede de atenção à saúde: trilhando os caminhos da integralidade. Esc Anna Nery. 2013;17(4):603-10.

4. Kerber NP, Kirchhof AL, Cezar-Vaz MR. Home care assistance and the right to health: an experience in the Brazilian net. Acta Paul Enferm. 2010; 23(2):244-50.

5. World Health Organization (WHO). European Ministerial Conference on Health Systems "Health Systems, Health and Wealth", Tallinn, Estonia 2527 June 2008: report. Copenhagen: WHO Regional Office for Europe; [Internet]. 2009 [cited 2015 Nov 12]. Available from: http://www.euro.who. int/_data/assets/pdf_file/0006/78918/E92150. pdf

6. Conselho Federal de Enfermagem (COFEN). Resolução COFEN № 0464/2014 [Internet]. [citado 2015 fev 20]. Disponível em: http://www.cofen. gov.br/resolucao-cofen-no-04642014_27457. html

7. Silveria A, Neves TE. Crianças com necessidades especiais em saúde: cuidado familiar na preservação da vida. Cienc Cuid Saude. 2012;11(1):74-80.

8. Rezende JM, Cabral IE. As condições de vida das crianças com necessidades especiais de saúde: determinantes da vulnerabilidade social na rede de cuidados em saúde as crianças com necessidades especiais de saúde. R Pesq Cuid Fundam online [Internet]. 2010 [citado 2015 nov 12]; 2(Supl):22-5. Disponível em: http://www. seer.unirio.br/index.php/cuidadofundamental/ article/view/773/pdf_68

9. Neves ET, Cabral IE. Cuidar de crianças com necessidades especiais de saúde: desafios para as famílias e enfermagem pediátrica. Rev Eletr Enf [Internet]. 2009 [citado 2015 nov 12];11(3):52738. Disponível em: http://www.fen.ufg.br/ revista/v11/n3/v11n3a09.htm

10. Drucker LP. Rede de suporte tecnológico domiciliar à criança dependente de tecnologia egressa de um hospital de saúde pública. Cienc Saude Coletiva. 2007; 12(5):1285-94. 
11. Vernier ETN, Cabral IE. Caracterização de crianças com cuidados especiais de saúde e seus familiares cuidadores. Santa Maria (RS). 2004 - 2005 subsídios para intervenções de enfermagem. Rev Soc Bras Enferm Ped. 2006; 6(1):37-45.

12. Arrué AM, Neves ET, Mathias CV, Jantsch LB, Naidon AM, Pieszak GM. Crianças com necessidades especiais de saúde egressas de terapia intensiva neonatal. Evidentia. [Internet]. 2014 [citado 2015 nov 12];11(45). Disponível em: http://www. index-f.com/evidentia/n45/ev8091p.php

13. Silva KL, Sena R, Leite JCA, Seixas CT, Gonçalves AM. Internação domiciliar no SUS. Rev Saúde Pública. 2005; 39(3):391-7.

14. Oliveira AR, Costa AG, Araujo TL, Aquino PS, Pinheiro AK, Ximenes LB. Competências essenciais de programas de assistência domiciliar para pacientes com acidente vascular cerebral. Rev Eletr Enf. [Internet]. 2013 [citado 2015 nov 12];15(2):317-25. Disponível em: https://www. fen.ufg.br/revista/v15/n2/pdf/v15n2a02.pdf
15. Machado RA, Dellegrave D, Silveira DS, Lemões MA. O cuidador familiar no foco do programa de assistência domiciliar de uma unidade básica de saúde no município de Porto Alegre. Rev Enferm Saúde. 2011; 1(1):39-49.

16. Martelli DRB, Silva MS, Carneiro JA, Bonan PRF, Rodrigues LHC, Martelli-Júnior H. Internação domiciliar: o perfil dos pacientes assistidos pelo Programa HU em Casa. Physis. 2011; 21(1):14757.

17. Machado AL, Silva MJ, Freitas CH. Assistência domiciliária em saúde: um olhar crítico sobre a produção científica de enfermagem. Rev Bras Enferm. 2011; 64(2):365-9.

18. Serafim AP, Ribeiro RA. Internação domiciliar no SUS: breve histórico e desafios sobre sua implementação no Distrito Federal. Com Ciênc Saúde. 2011; 22(2):163-8. 